\title{
Beware of Blockbusters and Mega Movies
}

\section{Clarence W Thomas*}

School of Mass Communications, Virginia Commonwealth University, USA

We live in an era of Mega, Blockbuster films such as Titanic, Star Wars, Harry Potter, Spider Man, and others. These films can cost over 100 million dollars to make. To date, Titanic has generated gross profits over 600 million dollars. In their quest to profit from entertaining us, the producers of such films have expectations of making hundreds of millions of dollars.

Good Night and Good Luck is not a Mega film. In fact, this reviewer saw the film in a small, two-screen theater. The $10,15,20$, screen multi-cinemas in the area were not showing it. However, congratulations go to Director-Writer-Actor, George Clooney, as well as his cast and crew, for making this relatively low budget (7.5 million dollar) yet, highly socially relevant film. Clooney successfully utilizes the small film to cover and convey the importance of two big historical topics: the impact of McCarthyism/Red Scare and the emergence of broadcast (TV) journalism as a watchdog of government and facilitator of social justice.

Egbert Roscoe Murrow, better known as Edward R. Murrow, was a pioneer broadcast journalist. He joined CBS in 1935 as Director of Talks and Education. Murrow went on to host an abundance of lively informative radio and TV news programs including: This is London, Hear It Now, See It Now, Person to Person, CBS Reports, and others. The Emmy and Peabody Award winner is best known for his war coverage and investigative journalism. Both war coverage (with embedded journalists) and investigative journalism (with many 60 minutes style shows) are now staples of TV news. Murrow's work and career led to his induction into the Radio Hall of Fame in 1988.

Good Night and Good Luck concentrates on one episode of Murrow's broadcasting career. Namely, the story of the challenge by Murrow (David Strathairn) and CBS news Chief Fred Friendly (George Clooney) of Senator Joseph McCarthy and McCarthyism is presented. The film follows the story of the Senator from Wisconsin as he uses the techniques of guilt by assertion, association and innuendo to crusade against communism. McCarthy attacks U.S. citizens from all walks of life and counter attacks Murrow. The film concludes with the ultimate downfall of McCarthy and the uplifting of freedom of speech and freedom of the press.

In addition to the obvious themes of McCarthyism/Red Scare, the film also presents the sub-theme of the media as big business with a bottom line mentality versus the notion of the media as a facilitator of social responsibility in a free society. This sub-theme unfolds as CBS owner William S. Paley (Frank Langella), clashes with Murrow and Friendly over the price (literally and figuratively) that CBS will pay as a result of the Murrow-McCarthy confrontation.

David Strathairn does a very believable job in his portrayal of Murrow. Strathairn manages to capture cadence of Murrow's voice, speech, and unique style of news delivery. Excellent writing and acting allows Strathairn to present and project respectively Murrow's constant and rather strong sarcastic humor on and off camera.

The mood, atmosphere, and setting of the film are greatly and positively influenced by several factors including music, black and white film, fashion, and smoking (yes smoking).

First, the use of a jazz soundtrack and performances by real life jazz singer, Dianne Reeves makes the viewer feel part of the times. Reeves, in period costume, sing several songs of the era interspersed in the storyline. In addition, lilting jazz saxophone melodies provide background throughout the film.

Next, the use of black and white film allows the film makers to match the appearance of the film stock of the day. More importantly, the use of black and white allow for a seamless and very effective combination of actual footage of McCarthy, Senate Hearings, and the staged footage of Strathairn as Murrow.

The fashion of the period is flawlessly recreated. No stone is left unturned in terms of the authentic looking costumes for all cast members-from the journalists, to the politicians, to the jazz performers.

Last, but not least, the use of smoking definitely takes audience members to a time other than today. Just about every scene in the film employs the techniques of thick clouds of cigarette smoke to convey and portray something that Murrow and others actually did while facing the stress of the times (the smoke filled newsroom). The smoking also conveys the commonplace non-controversial nature of the practice at that time in history, as exemplified by an ad for Kent cigarettes. Ironically, the real Murrow died of lung cancer in 1965, at the age of 57.

As a Professor of media history and ethics, I expect my present and former students to be familiar with Murrow and other important historical figures. However, we live in a time when many youth and the man-on-the-street are not well acquainted with our history, including Murrow and McCarthy.

Through Good Night and Good Luck, George Clooney and company have done an excellent job of not just entertaining us, but educating us about an important part of our history, as well. Thankfully, in this film and in reality Murrow, social responsibility of the media and social justice win!

*Corresponding author: Clarence W Thomas, School of Mass Communications, Virginia Commonwealth University, USA, Tel: +1-804-827-3772; E-mail: cwthomas@vcu.edu

Received May 03, 2012; Accepted May 03, 2012; Published May 05, 2012

Citation: Thomas CW (2012) Beware of Blockbusters and Mega Movies. J Mass Commun Journalism 2e118. doi:10.4172/2165-7912.1000e118

Copyright: (C) 2012 Thomas CW. This is an open-access article distributed unde the terms of the Creative Commons Attribution License, which permits unrestricted use, distribution, and reproduction in any medium, provided the original author and source are credited. 